\title{
Mniejszość niemiecka w Polsce północnej okiem socjologa
}

\author{
Magdalena Lemańczyk, \\ Mniejszość niemiecka na Pomorzu Gdańskim, \\ Instytut Studiów Politycznych PAN, \\ Towarzystwo Kulturalne Ludności Niemieckiej \\ „Ojczyzna” w Kwidzynie, \\ Warszawa 2016, ss. 417.
}

Autorka recenzowanej książki, z wykształcenia socjolog, jest związana z Instytutem Kaszubskim w Gdańsku. Przez kilka lat wykładała w Wyższej Szkole Turystyki i Hotelarstwa w Gdańsku. Specjalizuje się w badaniach nad mniejszością niemiecką na Pomorzu Gdańskim, gdańskimi Niemcami oraz zachodnioprusakami mieszkającymi w Niemczech. Zajmuje się także zagadnieniami związanymi z pomorską wielokulturowością, współczesnymi stosunkami polsko-niemieckimi, migracjami oraz jakościowymi metodami i technikami badań socjologicznych. W 2013 roku w Instytucie Socjologii Uniwersytetu im. Adama Mickiewicza w Poznaniu obroniła z wyróżnieniem pracę doktorską na temat: „Tożsamość narodowa liderów mniejszości niemieckiej w wybranych miejscowościach Polski północnej”. Dysertacja została napisana pod kierunkiem prof. dr. hab. Cezarego Obracht-Prondzyńskiego z Uniwersytetu Gdańskiego - znanego w środowisku naukowym historyka, socjologa i antropologa. Omawiana monografia jest zmienioną i zaktualizowaną wersją niniejszej rozprawy doktorskiej i stanowi tym samym podsumowanie wieloletnich badań autorki nad tożsamością liderów mniejszości niemieckiej w Polsce północnej i działalnością organizacji zrzeszających tę mniejszość po przemianach społeczno-politycznych w Polsce w 1989 roku. 
Książka została wydana przez Instytut Studiów Politycznych PAN w Warszawie, a jej współwydawcą jest Towarzystwo Kulturalne Ludności Niemieckiej „Ojczyzna” w Kwidzynie. Recenzentem książki jest prof. dr hab. Andrzej Sakson z UAM w Poznaniu.

Recenzowana publikacja jest pierwszą socjologiczną monografią poświęconą mniejszości niemieckiej na Pomorzu Gdańskim po przełomie społeczno-politycznym w 1989 roku. Do tej pory mniejszość niemiecka na omawianym terenie nie stanowiła przedmiotu pogłębionych studiów, badań socjologicznych, stanowiąc jedynie tło socjologicznych analiz w artykułach niektórych badaczy zajmujących się mniejszością niemiecką w Polsce czy ludnością rodzimą na Pomorzu. Monografia uzupełnia lukę w przeprowadzonych dotychczas badaniach socjologicznych w innych częściach naszego kraju, tj. na Górnym Śląsku, Warmii i Mazurach, Dolnym Śląsku, w Wielkopolsce oraz Pomorzu Zachodnim. Autorka dzięki tej publikacji dołączyła do ścisłego grona specjalistów zajmujących się badaniami nad mniejszością niemiecką w Polsce.

Warto zwrócić uwagę na obszar badawczy, na którym zostały przeprowadzone badania: Pomorze Gdańskie. Lemańczyk dokładnie precyzuje i wyjaśnia ten obszar. Był on nazywany w przeszłości różnie: Pomerania, Pommerellen, Pomorze Wschodnie, Pomorze Nadwiślańskie, Prusy Królewskie, Prusy Zachodnie. Swoim badaniem objęła stowarzyszenia mniejszości niemieckiej funkcjonujące po ostatnim podziale administracyjnym kraju w 1999 roku na terenie województwa pomorskiego, części województwa kujawsko-pomorskiego, części województwa warmińsko-mazurskiego oraz północnej części województwa wielkopolskiego. Położenie większości stowarzyszeń pokrywa się w znacznej części z terenem byłej niemieckiej prowincji Prusy Zachodnie (1878-1920) oraz terytorium byłego drugiego Wolnego Miasta Gdańska (1920-1939). Ze wglądu na powiązania historyczne i instytucjonalne uwzględniła ona w swoim badaniu także organizacje tej mniejszości mające swe siedziby na terenie byłej prowincji Pomorze. Autorka zdaje sobie wyśmienicie sprawę z nieprzystawalności nazw historyczno-geograficznych, które określają wybrany obszar badawczy. Chcąc jednak klarownie wyjaśnić czytelnikowi zachodzące procesy narodowościowe w odniesieniu do sytuacji po II wojnie światowej, zdecydowała się na użycie w monografii nazwy Pomorze Gdańskie. Argumentem przemawiającym za tym jest także fakt, że największym ośrodkiem miejskim w województwie, na Pomorzu Gdańskim, a zarazem w tej części Polski, jest Gdańsk. Miasto to po wojnie stało się swoistym centrum oddziaływania politycznego, kulturalnego i ekonomicznego na badanym obszarze, $w$ tym przy powstawaniu, rozwoju i działalności stowarzyszeń mniejszości niemieckiej po 1989 roku na Pomorzu Gdańskim. Na marginesie warto wspomnieć, że stowarzyszenie mniejszości niemieckiej w Gdańsku stanowi największą organizację tejże mniejszości narodowej w tym regionie.

Autorka w sposób fachowy przedstawia socjologiczny obraz mniejszości niemieckiej na Pomorzu Gdańskim przez pryzmat tożsamości narodowej i etnicznej jej liderów oraz ich etnicznej działalności i zaangażowania po 1989 roku. Bada i analizuje ich motywy zakładania, wstępowania do organizacji, kontakty ze środowiskami w Niemczech, relacje na poziomie rodziny. Przedstawiając poszczególne istniejące w regionie organizacje tej mniejszości, ukazuje ich działalność, kondycję i położenie w szerokim ogólnopolskim kontekście. Prezentuje studium przypadku układu społecznego, jakim są organizacje mniejszości niemieckiej, ze szczególnym uwzględnieniem struktury zasad funkcjono- 
wania, relacji wewnątrz- i zewnątrzgrupowych oraz wewnętrznej dynamiki tego układu. Celem monografii jest zweryfikowanie i uporządkowanie wiedzy na temat niemieckiej mniejszości narodowej we współczesnej Polsce w skali regionalnej i ogólnopolskiej.

Wnioski zawarte w niniejszej monografii stanowią efekt badań socjologicznych przeprowadzonych przez autorkę w latach 2006-2009. Badanie objęło 160 liderów 19 organizacji mniejszości niemieckiej (wszystkie organizacje, które tam istnieją) na omawianym obszarze, wykorzystując triangulację jakościowych metod i technik badawczych, m.in.: metodę badań terenowych i obserwacji uczestniczącej w klasycznym ujęciu Bronisława Malinowskiego, technikę wywiadu kwestionariuszowego, technikę wywiadu zogniskowanego, metodę analizy treści (w tym analiza dokumentów archiwalnych). Tu warto wspomnieć, że autorka wykorzystała podczas badania charakterystyczną dla Floriana Znanieckiego metodę autobiograficzną uwzględniającą obiektywną stronę działania społecznego: kontekst sytuacji społecznej oraz subiektywną stronę: postawy społeczne. Przyjęła wprost metodę dokumentów „obiektywnych”, analizując kroniki organizacji mniejszości niemieckiej, listy, raporty, protokoły zebrań, sprawozdania z działalności kulturalnej, korespondencje służbowe i prywatne oraz dostępne artykuły prasowe. To nadało częściowo kierunek analizom prezentowanym w książce. Należy podkreślić, że chociaż badania miały charakter jakościowy, to można uznać je za reprezentatywne w skali analizowanego regionu.

Przeprowadzone badania są oparte na starannie dobranych i właściwie zastosowanych teoriach socjologicznych, zarówno tych najstarszych, klasycznych, jak i najnowszych. $\mathrm{Z}$ tego chociażby względu na uwagę zasługuje świetny warsztat socjologiczny autorki. Lemańczyk udowadnia znajomość teorii socjologicznych oraz - co istotniejsze - umiejętność ich zastosowania w praktyce.

Co do podmiotu badania, są nimi liderzy mniejszości niemieckiej w Polsce północnej. Przez liderów mniejszości niemieckiej autorka rozumie z jednej strony formalnych przewodniczących i członków zarządów, a z drugiej strony osoby opiniotwórcze, animujące działalność kulturalną instytucji, ale niebędące we władzach lub po prostu osoby aktywnie działające w ramach instytucji.

O samym wyborze osób, jako podmiotu badań, zadecydowało kilka bardzo ważnych czynników. Osoby te musiały być silnie zakorzenione w badanym środowisku i dobrze zorientowane $\mathrm{w}$ funkcjonowaniu organizacji. Formalni liderzy dysponujący odpowiednimi zasobami organizacyjnymi (władzą, środkami finansowymi, informacją) mają możliwość wpływania na działalność badanych organizacji. Są wyrazicielami istotnych norm i wartości grupowych, skupiają zróżnicowane dążenia i oczekiwania pozostałych członków. Dotychczasowi przewodniczący lub założyciele organizacji są nieocenionym źródłem informacji dotyczących początków instytucjonalizacji mniejszości niemieckiej w regionie. Wszyscy oni są reprezentantami nie tylko opisywanej i analizowanej grupy, ale także całego ruchu mniejszości w regionie.

Konstrukcja niniejszej monografii wynika z założeń celów badawczych i przyjętej całościowej perspektywy badawczej. Książka ma w zasadzie charakter problemowy, jednak w rozdziale drugim ma charakter chronologiczny. Natomiast w związku z analizami zachodzących zjawisk w całej grupie lub w jej części w poszczególnych rozdziałach książka przybiera często formę mieszaną, tj. formę problemowo-chronologiczną. 
Monografia składa się z czterech rozdziałów, a każdy z nich z kilku tematycznych podrozdziałów. Książkę uzupełniają bibliografia oraz aneksy zawierające wybrane dokumenty, tabele i mapy. Warto dodać, że publikacja została opatrzona posłowiem prof. dr. hab. Piotra Madajczyka. Obszerny materiał ilustracyjny, na który składają się w większości fotografie autorstwa Magdaleny Lemańczyk, wzbogaca monografię, przybliżając czytelnikowi osoby i wydarzenia związane z działalnością mniejszości niemieckiej na Pomorzu Gdańskim.

Rozdział pierwszy został poświęcony stosunkom narodowościowym na Pomorzu Gdańskim. Autorka scharakteryzowała w sposób syntetyczny panujące stosunki narodowościowe w XX wieku, uwzględniając przy tym wielowiekową specyfikę tego obszaru i zamieszkujących go grup - przede wszystkim Kaszubów, Polaków i Niemców. Skupiła się na przedstawieniu wpływów prusko-niemieckich i polskich na mieszkańców omawianego obszaru, ukazaniu zachodzących procesów społecznych i politycznych, jak np. emigracja ludności niemieckiej w okresie międzywojennym, okres okupacji niemieckiej i II wojny światowej na Pomorzu Gdańskim, powojenny los Niemców, politykę „odniemczania" prowadzoną przez państwo polskie oraz położenie ludności rodzimej w okresie powojennym aż do przełomu społeczno-politycznego w 1989 roku.

W tej części historycznej książki brakowało mi jednak pełniejszej informacji, jak rozwijała się w okresie rozbiorowym identyfikacja rodzimych mieszkańców Pomorza $\mathrm{z}$ narodem polskim, z kaszubskością i na czym ona polegała. W dalszej części rozdziału zabrakło mi szerszego i wnikliwszego opisu sytuacji stosunków międzyludzkich Polaków-Kaszubów-Niemców w kontekście narodowościowym. Natomiast w tej części znajdziemy dobry syntetyczny obraz prowadzonej polityki narodowościowej przez Niemców do 1945 roku i Polaków po zakończeniu II wojny światowej oraz opis istniejących w regionie narodowościowych i etnicznych proporcji wyrażonych w procentach. Na pewno w tym rozdziale czytelnik znajdzie odpowiedź na pytanie, co kształtowało tożsamość rodzimych mieszkańców tego obszaru na przestrzeni wieków, ale nie za wiele dowie się o tym, jak wyglądały w tym czasie stosunki narodowościowe pomiędzy danymi grupami narodowościowymi i etnicznymi, jak ze sobą ludzie koegzystowali, jakie były stosunki między poszczególnymi grupami, jak się one między nimi układały.

Druga część książki dotyczy niezwykle ciekawego procesu, jakim jest instytucjonalizacja mniejszości niemieckiej w północnej części naszego kraju po 1989 roku. Proces ten został przedstawiony przez autorkę w sposób ciekawy i klarowny, a co ważniejsze - w perspektywie nie tylko regionalnej, ale całego kraju. W tym celu wykorzystała ona niektóre koncepcje teoretyczne mieszczące się w nurcie teorii ruchów społecznych, m.in. koncepcję mobilizacji zasobów społecznych, politycznych i ekonomicznych, konstrukcjonistyczną koncepcję „ramy” oraz elementy kulturalistycznego systemu socjologii Floriana Znanieckiego.

Lemańczyk ukazuje czytelnikowi w tym rozdziale socjologiczną i historyczną analizę procesów mających wpływ na obecny kształt instytucjonalny, uwarunkowania społeczno-polityczne powstawania i działalności organizacji mniejszości niemieckiej. Prezentuje wszystkie powstałe organizacje w Polsce północnej (w tym także te, które już zaprzestały swojej działalności). Kompleksowo i w jasny sposób przedstawia nie tylko działalność tych organizacji (koleje powstawania i funkcjonowania organizacji mniejszości 
niemieckiej, w tym ich sukcesy, konflikty czy porażki), ale także strukturę organizacyjną mniejszości niemieckiej na omawianym obszarze badawczym, w tym meandry decentralizacji struktur centralnej instytucji mniejszości niemieckiej w województwie pomorskim: Związku Mniejszości Niemieckiej w Gdańsku i powstawania jego oddziałów terenowych. Ciekawą częścią tego rozdziału jest przedstawienie i omówienie działalności samodzielnych stowarzyszeń mniejszości niemieckiej, a co ważne - wyjaśnienia, dlaczego doszło do ich powstania i usamodzielnienia. Autorka prezentuje także w tym rozdziale naczelną organizację mniejszości niemieckiej w Polsce - Związek Niemieckich Stowarzyszeń Społeczno-Kulturalnych w Polsce z siedzibą w Opolu, zwłaszcza jego powstanie oraz cele i zadania, które mu przyświecają. Ponadto wymienia i opisuje najważniejsze stowarzyszenia mniejszości niemieckiej istniejące w Polsce. Było to niezbędne, aby czytelnikowi jak najlepiej i najszerzej ukazać uwarunkowania społeczno-polityczne funkcjonowania organizacji mniejszości niemieckiej w skali ogólnopolskiej.

$\mathrm{Na}$ uwagę w tym rozdziale zasługuje zaprezentowanie przez autorkę, co stanowi w literaturze swoiste novum, specyficznej grupy niemieckich gdańszczan, działających w ramach Związku Mniejszości Niemieckiej w Gdańsku, tzw. Danziger Club (Klub Gdańszczan). Członkowie tej grupy noszą miano: Danzigerzy (spolszczona forma od nazwy mieszkańców Gdańska w języku niemieckim: Danziger). Należy zgodzić się z autorką, że termin ten najlepiej wpisuje się w narrację genealogiczną, obywatelską i kulturową grupy gdańszczan niemieckiego pochodzenia żyjących w swojej ojczyźnie, obywateli byłego Wolnego Miasta Gdańska. Jednak autorka - moim zdaniem - nie do końca w tym rozdziale wytłumaczyła czytelnikowi, jak wygląda i na czym polega działalność Klubu Gdańszczan. Czyni to dopiero w następnych rozdziałach - w trzecim, przy opisie dynamiki konfliktów w stowarzyszeniach mniejszości niemieckiej w regionie, oraz czwartym (szczególnie w tej części), przedstawiając motywy powoływania organizacji mniejszości niemieckiej i członkostwa.

Ponadto w omawianym rozdziale autorka, pisząc o fakcie zmniejszania się w polskim parlamencie liczby osób reprezentujących interesy mniejszości niemieckiej w Polsce, nie wytłumaczyła, chociażby krótko, dlaczego tak się dzieje. Moim zdaniem mogła poświęcić zaledwie mały fragment (chociażby np. w formie odnośnika) temu ważnemu zjawisku. Przede wszystkim informując i wyjaśniając czytelnikowi, dlaczego z perspektywy lat liczba głosów na kandydatów mniejszości niemieckiej podczas wyborów parlamentarnych zmniejsza się, natomiast rośnie podczas wyborów samorządowych.

Co do wspomnianych w niniejszym rozdziale danych o liczebności mniejszości niemieckiej uzyskanych podczas ostatniego przeprowadzonego Narodowego Spisu Powszechnego (NSP) z 2011 roku, autorka opiera się jedynie na wstępnych jego wynikach. Szkoda, że przygotowując pracę do wydania nie udało jej się dostatecznie wykorzystać istniejącej już od kilku lat wiedzy i literatury odnośnie do spisu powszechnego z 2011 roku. Tym samym po uwzględnieniu najnowszej literatury przedmiotu mogłaby w zasadzie nie ograniczać się do porównania wyników badań własnych przede wszystkim z wynikami NSP z 2002 roku, ale jeszcze bardziej je poszerzyć o aktualne, dostępne i opisane wyniki NSP 2011. Zasadniczo jednak nie wpływa to na merytoryczne wnioski dotyczące liczebności współczesnej mniejszości niemieckiej. 
Trudno mi zgodzić się ze stwierdzeniem autorki, że gdańskie koło Związku Młodzieży Mniejszości Niemieckiej w RP (w skrócie z języka niemieckiego - BJDM) współpracuje i utrzymuje kontakty z członkami m.in. Związku Studentów Niemieckich w Polsce (zob. s. 153). Po pierwsze dlatego, że użyła zbyt ogólnej nazwy, nie podała siedziby związku, a tym samym nie wiadomo, którego związku to dotyczy, ponieważ do niedawna w Polsce działały dwa tego typu związki studenckie: jeden z siedzibą w Opolu, a drugi w Raciborzu (już nie istnieje), a po drugie - słowo współpraca i utrzymywanie kontaktów przez BJDM w Gdańsku z członkami jednego czy drugiego (jeszcze jako działającego) związku studenckiego nie odpowiada rzeczywistości. Wiem co piszę, ponieważ moja rozprawa doktorska została poświęcona młodzieży mniejszości niemieckiej na Górnym Śląsku, w obydwu związkach przeprowadzałem badania, a do dnia dzisiejszego mam dobre kontakty z członkami tych niemieckich korporacji studenckich. W rzeczywistości do (nieformalnego) kontaktu między (paroma) członkami tych organizacji młodzieżowych doszło, ale nigdy do formalnej współpracy, a ponadto nie są utrzymywane między nimi kontakty.

Poza wyżej wspomnianymi uwagami czy zastrzeżeniami rozdział ten można zaliczyć do najciekawszych i najcenniejszych w tej książce.

W rozdziale trzecim, przedstawiając charakterystykę stosunków społecznych w ramach stowarzyszeń mniejszości niemieckiej, autorka gruntownie omówiła kwestie dotyczące współpracy wewnątrzgrupowej mniejszości niemieckiej (pomiędzy stowarzyszeniami mniejszości niemieckiej, przy tym także istniejące konflikty między poszczególnymi organizacjami mniejszości niemieckiej) oraz jej współpracę z instytucjami zewnętrznymi (organizacjami partnerskimi z Niemiec, organizacjami wspierającymi, polskimi i niemieckimi władzami oraz organizacjami pozarządowymi). Dzięki tej części czytelnik mógł zaznajomić się z typami stosunków społecznych odnośnie do mniejszości niemieckiej oraz z mechanizmami, na podstawie których odbywa się jej współpraca wewnątrz- i zewnątrzgrupowa. Tym samym czytelnik ma możliwość zapoznania się nie tylko z siecią powiązań instytucjonalnych mniejszości niemieckiej, ale również z najważniejszymi kierunkami, priorytetami i specyfiką jej działalności. Szczególnie cenny jest opis form aktywności społeczno-kulturalnej organizacji mniejszości niemieckiej na omawianym obszarze badawczym w poszczególnych fazach instytucjonalizacji, a zwłaszcza wyszczególnione lokalne odrębności w prowadzonej działalności stowarzyszeń.

Przede wszystkim na uwagę $\mathrm{w}$ tym rozdziale zasługują wymienione przez autorkę trzy fazy instytucjonalizacji mniejszości niemieckiej w tej części Polski. Cechują się one zróżnicowanym poziomem aktywności etnicznej, a zarazem społeczno-kulturalnej. Pierwsza faza to faza rozwoju i przyśpieszenia aktywności etnicznej mniejszości niemieckiej w latach dziewięćdziesiątych XX wieku. Druga to faza stabilizacji i stagnacji aktywności etnicznej w latach 2000-2004. Natomiast trzecia to faza regresu tej aktywności od 2005 roku. Warto zauważyć, że te trzy fazy instytucjonalizacji mniejszości niemieckiej można jak najbardziej wyróżnić także w innych regionach Polski, w tym na terenie historycznego Górnego Śląska (województwa: śląskie i opolskie), gdzie znajdują się największe skupiska mniejszości niemieckiej. Jedyną uwagę miałbym, że na Górnym Śląsku cezury poszczególnych faz są podobne, lecz niedokładnie takie same. W kolebce mniejszości niemieckiej w Polsce, tj. na Górnym Śląsku, procesy instytucjonalizacji zachodziły podobnie, jednak zwłaszcza w przypadku pierwszej fazy trwała ona nieco krócej niż na 
innych obszarach kraju. Tym samym lata stabilizacji zaczęły się na ziemi górnośląskiej w drugiej połowie lat dziewięćdziesiątych ubiegłego wieku. Regres aktywności etnicznej zaś generalnie zachodzi w całym naszym kraju od połowy pierwszej dekady XXI wieku.

Autorka wspomina o zaangażowaniu asystentów ds. kultury IfA (Institut für Auslandsbeziehungen). Raz pisze asystentka ds. kultury IfA, a innym razem menadżerka ds. kultury IfA (s. 235-236). W zasadzie chodzi o to samo stanowisko pracy i zapewne nie ujednolicając nazwy, w ten sposób, tj. zamienny, stosuje te nazwy. Prawidłowa nazwa w języku niemieckim brzmi asystent(-ka) ds. kultury (Kulturassistent(-in)), natomiast nazwa menadżer(-ka) ds. kultury jest nieraz stosowana w umowach zawieranych przy zatrudnianiu w Polsce. Przez wyżej wspomniany Instytut Stosunków Zagranicznych ze Stuttgartu asystenci są wysyłani do organizacji mniejszości niemieckiej w Europie Środkowej, Południowo-Wschodniej i Wschodniej, aby swoją pracą przede wszystkim wzmocnić kulturową tożsamość mniejszości niemieckiej poprzez rozwój i pielęgnację niemieckiej mowy i kultury oraz wspierać integrację społeczną mniejszości niemieckiej. Asystenci pomagają w przygotowywaniu i organizowaniu projektów, np. takich jak: przedstawienia, koncerty, wystawy, odczyty, projekcje filmów niemieckich, spotkania, wycieczki i seminaria, kursy języka niemieckiego. Ponadto, jako asystenci ds. mediów, pracują lub pomagają w pracy redakcjom niemiecko- lub dwujęzycznych gazet, programów radiowych i telewizyjnych mniejszości niemieckiej.

Ostatnia, a zarazem kluczowa część monografii - rozdział czwarty - jest poświęcony autoidentyfikacji narodowej i etnicznej liderów mniejszości niemieckiej. Lemańczyk ukazuje czytelnikowi specyfikę ich autoidentyfikacji, ich zróżnicowanie wynikające z charakteru obszaru pogranicza kulturowego oraz zasadniczo odmienne stosunki narodowościowe na Pomorzu będące następstwem zmian politycznych i społeczno-kulturowych dokonujących się na przestrzeni wieków. Autorka, przedstawiając wyniki badań dotyczących tożsamości liderów mniejszości niemieckiej, określiła wartości rdzenne (szczególnie język i wspólnotę pamięci, zgodnie z koncepcją Jerzego Smolicza) oraz wachlarz typów autoidentyfikacji (poprzez zbadanie samopostrzegania się przez liderów, jak się autoidentyfikują, kim są, kim się czują, jakiego języka używają, czym jest dla nich ojczyzna w rozumieniu Stanisława Ossowskiego) w układzie tożsamościowo-terytorialnym.

Warto podkreślić, że analizując tożsamość narodową i etniczną liderów mniejszości niemieckiej na Pomorzu Gdańskim w okresie III Rzeczypospolitej Lemańczyk bardzo słusznie uwzględniła skomplikowany kontekst historyczny i wielowiekową tradycję stosunków narodowościowych, etnicznych i wyznaniowych na tym terenie. Ziemie pomorskie wchodziły w poszczególnych okresach w skład wielu różnych organizmów administracyjno-państwowych o zróżnicowanych strukturach politycznych i składzie wyznaniowo-narodowościowym. Na stosunki ludnościowe na Pomorzu miały wpływ centra polityczne, kulturowe i ekonomiczne Niemiec (Prus) i Polski. Zachodzące procesy społeczno-polityczne $\mathrm{w}$ regionie oddziaływały na relacje między zamieszkałymi w nim przede wszystkim Kaszubami, Polakami i Niemcami. Przybierały one najróżniejszy charakter, zwłaszcza w kategoriach asymetrii położenia, płynnej struktury tożsamościowej (narodowej i etnicznej) oraz odmienności językowych i wyznaniowych. Skutki tych zjawisk odgrywają znaczącą rolę w kształtowaniu się tożsamości narodowej nie tylko współczesnych liderów, ale także członków mniejszości niemieckiej w Polsce północnej. 
Lemańczyk podkreśla, że na różnorodność tożsamości narodowej i etnicznej składa się także wiele innych czynników, jak chociażby wiek czy socjalizacja w odmiennych warunkach. Skutkiem tego jest, że podziały identyfikacyjne przebiegają nawet w najbliższej rodzinie. Do tego należy dodać, że w mniejszości niemieckiej na Pomorzu jest bardzo wiele małżeństw mieszanych, nie tylko z Polakami, ale również z członkami innych mniejszości, np. Ukraińcami. Te podziały ujawniają się najczęściej na poziomie życia codziennego, przy spotkaniach rodzinnych. Jest inna kultura jedzenia, inne nazwy potraw, nazewnictwo członków rodziny: u jednych kuzyn, a u drugich brat cioteczny.

Wyniki jej badań wskazują także, że znaczną część aktywnych członków organizacji mniejszości niemieckiej na obszarze byłej prowincji niemieckiej Prusy Zachodnie stanowią przedstawiciele ludności autochtonicznej: Kaszubi i (w mniejszej mierze) Kociewiacy, którzy w indywidualnych konstrukcjach tożsamościowych w różnorodny sposób ujmują i waloryzują niemiecko-polsko-kaszubski/kociewski splot kulturowy.

Analizy autoidentyfikacji liderów mniejszości niemieckiej autorka dokonała na podstawie kategoryzacji społeczności tworzącej mniejszość niemiecką w Polsce autorstwa Andrzeja Saksona oraz Zbigniewa Kurcza, podkreślając tożsamościowo-terytorialne odrębności w badanym regionie. Pod koniec rozdziału podsumowała wielowątkowe rodzaje autoidentyfikacji liderów mniejszości niemieckiej, wymieniając kategorie tożsamości zaproponowane przez Johna Miltona Yingera: tożsamość pełną, prywatną oraz kombinacje tożsamości nieuznawanej, wyobrażeniowej i ukrytej. Należy zgodzić się, że kategorie te najbardziej klarownie odzwierciedlają różnorodność autoidentyfikacji badanych liderów.

Książka jest wyśmienitym socjologicznym opisem tożsamości liderów mniejszości niemieckiej na Pomorzu Gdańskim oraz działalności stowarzyszeń niemieckiej mniejszości narodowej w tej części Polski. Autorka prezentuje świetny warsztat socjologiczny, nie tylko w teorii, ale w terenie i podczas analiz. Dzięki szeroko zakrojonym badaniom oraz dogłębnym analizom czytelnik może zapoznać się z pełnym spektrum czynników kształtowania się tożsamości liderów i procesu instytucjonalizacji mniejszości niemieckiej w Polsce północnej. Problematyka poruszana w niniejszej monografii wpisuje się w tradycję badań socjologicznych na Ziemiach Zachodnich i Północnych.

Książka zasługuje na uznanie, a czyta się ją z niesłabnącym zainteresowaniem. Jest to praca wartościowa i wnosi istotny wkład do literatury przedmiotu. Przede wszystkim wypełnia lukę w literaturze przedmiotu dotyczącą mniejszości niemieckiej na Pomorzu Gdańskim. Zachęcam do przeczytania monografii nie tylko osoby, które interesują się mniejszością niemiecką w Polsce, ale także tych, którzy interesują się historią i mieszkańcami omawianego obszaru badawczego oraz wzajemnymi kontaktami Polaków, Kaszubów i Niemców. 